Матвєєва Катерина Сергіївна кандидат педагогічних наук, доцент кафедри іноземних мов Миколаївського національного аграрного університету, вул. Георгія Гонгадзе, 9, м. Миколаїв, 54000, тел.: (051) 240-91-31, e-mail: matveeva@mnau.edu.ua, https://orcid.org/0000-0003-0974-3022

Марченко Дмитро Дмитрович кандидат технічних наук, заступник декана 3 навчальної роботи інженерно-енергетичного факультету, доцент кафедри тракторів та сільськогосподарських машин, експлуатації і технічного сервісу Миколаївського національного аграрного університету, вул. Георгія Гонгадзе, 9, м. Миколаїв, 54000, тел.: (051) 240-91-31, e-mail: marchenkodd@mnau.edu.ua, https://orcid.org/0000-0002-0808-2923

Курепін Вячеслав Миколайович кандидат економічних наук, старший викладач кафедри методики професійного навчання Миколаївського національного аграрного університету, вул. Георгія Гонгадзе, 9, м. Миколаїв, 54000, тел.: (051) 240-91-31, e-mail: kypinc@ukr.net, https://orcid.org/0000-00034383-6177

\title{
НАПРЯМКИ РОБОТИ СІМЕЙНОГО ПЕДАГОГА У СТРУКТУРІ ТЕРИТОРІАЛЬНОГО ЦЕНТРУ СОЦІАЛЬНОЇ ДОПОМОГИ СІМ'Ї ТА ДІТЯМ
}

Анотація. У нашій дослідницькій діяльності на початковому етапі вважаємо розгляд методу соціального діагностування, найбільш вдалим який передбачає прояснення всіх обставин протікання його результатів. Ми застосовували цей метод при проходженні соціально-педагогічної практики в спеціальній (корекційній) загальноосвітній школі-інтернаті». Соціальний педагог даної установи як пріоритетний напрям вважає роботу з сім'єю, тому що саме в сім'ї найчастіше лежать причини соціально-психологічних проблем дітей. Ті чи інші порушення в здоров'ї, психологічному і фізичному поведінці, емоційній сфері, навчальної діяльності в дитини говорять про неблагополуччя в сім'ї.

Аналіз педагогічних досліджень показав, що формування у школярів моральних якостей майбутнього сім'янина визначалося як важливий аспект виховання на всіх етапах розвитку педагогічної науки. Однак проблема сутності і структури відносини старшокласника до сім'ї як соціально значущої цінності залишається недостатньо вивченою, не обгрунтований потенціал проектної діяльності в процесі формування даного особистісного утворення.

Виявляються такі протиріччя між соціальною та науковою актуальністю проблеми формування ставлення до родини як соціально значущої цінності і недостатньою орієнтацією вчителів на формування цього особистісного 
новоутворення; потенціалом проектної діяльності з присвоєння цінностей і його недостатнім використанням для формування ціннісної свідомості особистості; потенціалом аксіологічного середовища гуманітарної освіти для формування досліджуваного особистісного якості і відсутністю технологічного забезпечення цього процесу. Ставлення старшокласника до сім'ї як соціально значущої цінності буде розглядатися як результат присвоєння особистістю цінності «сім'я», усвідомлення ऑii як основи соціальної єдності і буде проявлятися в умінні конструювати образ майбутньої сім'ї в контексті їі соціальної значущості.

Дані протиріччя $\epsilon$ джерелом дослідницької проблеми, яка полягає в необхідності визначення сутності ставлення до родини як соціально значущої цінності і науковому обгрунтуванні процесу його формування в умовах проектної діяльності в навчанні гуманітарних дисциплін.

Ключові слова: соціальна педагогіка, сімейний педагог, групи ризику, діагностування, сім’я, планування діяльності.

Matvyeyeva Kateryna Serhiivna Candidate of Pedagogical Sciences, Associate Professor of the Department of Foreign Languages of the Mykolayiv National Agrarian University, George Gongadze St., 9, Mykolayiv, 54000, tel.: (051) 240-91-31, e-mail: matveeva@mnau.edu.ua,https://orcid.org/0000-0003-0974-3022

Marchenko Dmytro Dmytrovych Candidate of Technical Sciences, Deputy Dean for Academic Affairs of the Faculty of Engineering and Energy, Associate Professor of Tractors and Agricultural Machinery, Operation and Technical Service of Mykolayiv National Agrarian University, George Gongadze St., 9, Mykolayiv, 54000, tel.: (051) 240-91-31, e-mail: marchenkodd@mnau.edu.ua, https://orcid.org/00000002-0808-2923

Kurepin Vyacheslav Mykolayovych Candidate of Economic Sciences, Senior Lecturer of the Department of Methods of Vocational Training of Mykolayiv National Agrarian University, George Gongadze St., 9, Mykolayiv, 54000, tel.: (051) 240-91-31, e-mail: kypinc@ukr.net, https://orcid.org/0000-0003-4383-6177

\section{DIRECTIONS OF WORK OF A FAMILY TEACHER IN THE STRUCTURE OF THE TERRITORIAL CENTER OF SOCIAL ASSISTANCE FOR FAMILIES AND CHILDREN}

\footnotetext{
Abstract. In our research activities at the initial stage we consider the method of social diagnosis, the most successful of which involves clarification of all the circumstances of its results. We used this method when undergoing socio-pedagogical practice in a special (correctional) boarding school. " The social pedagogue of this institution considers work with the family as a priority, because it is in the family that the causes of children's social and psychological problems often lie. Certain disorders in health, psychological and physical behavior, emotional sphere, educational activities in a child indicate a problem in the family.
} 
The analysis of pedagogical researches has shown that formation at schoolboys of moral qualities of the future family man was defined as an important aspect of education at all stages of development of pedagogical science. However, the problem of the essence and structure of the high school student's attitude to the family as a socially significant value remains insufficiently studied, the potential of project activities in the process of forming this personal education is not substantiated.

There are such contradictions between the social and scientific urgency of the problem of forming the attitude to the family as a socially significant value and the insufficient orientation of teachers to the formation of this personal neoplasm; the potential of project activities for the assignment of values and its insufficient use for the formation of value consciousness of the individual; the potential of the axiological environment of humanities education for the formation of the studied personal quality and the lack of technological support for this process. The attitude of high school students to the family as a socially significant value will be seen as the result of assigning personal value "family", awareness of it as the basis of social unity and will be manifested in the ability to construct the image of the future family in the context of its social significance.

These contradictions are the source of the research problem, which is the need to determine the essence of the attitude to the family as a socially significant value and the scientific justification of the process of its formation in terms of project activities in the teaching of humanities.

Keywords: social pedagogy, family pedagogue, risk groups, diagnosis, family, activity planning.

Постановка проблеми. Кожна людина народжується в певній сім'ї і стаючи iii членом, стає і частиною суспільства. У сім'ї здійснюється основне виховання дитини, процес його поступового включення в життя суспільства, сприйняття моральних норм, вивчення певних позицій і ролей. Вплив сім'ї має велике значення для виховання духовних і суспільних потреб людини. Серйозний вплив надає сім'я на формування ставлення до навколишнього середовища, до людей, до праці, до суспільства в цілому. Крім того, в родині особливо яскраво проявляються риси солідарності і взаємної відповідальності.

Сім'я $є$ посередником між дитиною і суспільством. У разі невиконання сім'єю іiі функцій, страждає як весь внутрішній світ дитини, так і порушують його зв'язку з суспільством.

Соціальний педагог - спеціаліст здатний надати допомогу i підтримку в подоланні низки проблем, в тому числі і сімейних проблем.

Для цього необхідно реалізувати ряд завдань:

- розглянути становлення сім'ї як соціального інституту в українській соціо культурної традиції;

- дати визначення поняттю сім'ї та представити їі функції;

- виявити негативні і позитивні фактори розвитку сім'ї;

- розглянути різні типи сімей 3 точки зору необхідності соціально педагогічного втручання; 
- розглянути систему соціально - педагогічної підтримки сім'ї і дітям;

- визначити роль соціального педагога в сім'ї;

- розглянути методи і форми роботи сімейного соціального педагога 3 сім'єю «групи ризику»;

- дослідити метод соціального діагностування на практиці;

- проаналізувати рівень благополуччя в різних сім'ях.

Об'єктом дослідження служить сімейне виховання. Предметом же є діяльність соціального педагога щодо соціалізації особистості дитини в сім'ї.

У роботі використовуються i реалізуються такі методи: вивчення літературних джерел, бесіда, спостереження, анкетування, соціальне діагностування.

Аналіз останніх досліджень і публікацій. У житті кожної людини родина займає особливе місце. Прагнення до досконалості сім'ї, роду і племені було властиво нашим предкам. Сім'я посилювала почуття особистої відповідальності дорослих за виховання дітей, зміцнювала важливі оціночні категорії: авторитет батьків, подружній обов'язок, честь сім'ї. Заохочувалося прагнення брати собі дружин 3 хорошого роду. Таким родом вважався рід чесний, дружний, численний, здоровий. Українці, крім того, пред'являли ще й додаткові вимоги до хорошого роду - працьовитість, висока моральність, цнотливість, скромність, доброта, тобто приблизно ті ж вимоги, що і до окремої людини. Так досконалість особистості доповнювалося досконалістю сім'ї, всього племені [1]. В українській культурній традиції людина без сім'ї вважався скривдженим Богом. Мати сім'ю і дітей було також необхідно і природно, як працювати. Такі якості як доброта, терпимість, взаємне прощення образ переходили в хорошій сім'ї у взаємну любов. Лайка, заздрість, корисливість вважалися гріхом. Сварливість і нелагідність розглядалися як покарання долі і викликали жалість до їх носіїв. Треба було вміти поступитися, забути образу, відповісти добром чи промовчати. [1]

Сім'я - найдавніший інститут людського суспільства - пройшла складний шлях розвитку. Від родоплемінних форм гуртожитку, коли людина «без роду, без племені» узагалі не міг існувати, через «велику сім'ю», вмится під одним дахом кілька поколінь жили в тісному контакті 3 «ріднею», що включала численних родичів, до нуклеарною «ядерної» сім'ї, що складається тільки з батьків і дітей. Такий пройдений шлях [2]. Сучасна сім'я багато в чому відрізняється від сім'ї на початку століття, де чоловік - «господар», «годувальник» забезпечував життєдіяльність сім'ї, а жінка, мати, відповідала за побут і психологічне благополуччя сім'ї.

У наш час сім'я знаходиться на межі кризи. Руйнівні наслідки реформ позначилися на моральному кліматі в суспільстві. Перехід до ринкової системи, господарювання вельми болісно відбився на стані сім'ї як соціального інституту. Наше суспільство стикається 3 дуже складними проблемами. Це зумовлено збільшенням числа малозабезпечених сімей, міграцією сімей, у тому числі за межі держави; станом здоров'я населення, зміною традиційних ролей сім'ї, особливо жінок, зростанням кількості неповних сімей. Соціологи відзначають зростання числа асоціальних сімей i пророкують зниження життєвого рівня, 
падіння моральних підвалин сімейного виховання. Фактором сьогоднішнього життя стало насильство в сім'ї. Діти, позбавлені можливості творчого розвитку, поповнюють загони бомжів, правопорушників, виявляються схильні алкогольних і нікотиновим пристрастям. Всі ці проблеми призводять до розпаду сім'ї. Кожна третя дитина сьогодні виховується в неповній сім'ї, зростає кількість дітей народжених поза шлюбом, батьки ухиляються від виховання дітей.

Таким чином, завдання соціально - педагогічної діяльності полягає у зміцненні цінності, значущості та можливостей сім'ї як найважливішого 3 соціальних інститутів.

Для кожної людини існує 2 сім'ї. Та, з якої від вийшов, i та, яку він створив, i в якій він живе зараз. Різні автори розглядають поняття сім'ї по-різному.

О.М. Кравченко розглядає сім'ю, як дрібну клітинку суспільства. Один 3 основних соціальних інститутів. Сім'я як соціальний інститут проходить ряд етапів. Це:

- вступ у шлюб;

- народження 1-ї дитини;

- закінчення дітонародження (остання дитина);

- «пусте гніздо» - виділення з родини останнього дитини;

- припинення родини зі смертю одного з подружжя.

Як вважають соціологи суспільство тримається на «п'яти» стовпах: інститут сім'ї та шлюбу, держава, економічний інститут, інститут освіти, релігія [3]. І якщо один із цих «стовпів» зруйнується, то не буде суспільства. Адже сім'я - це будинок який би людей, тут закладаються основи людських відносин, відбувається перша соціалізація особистості [4].

Ю.В. Васильків розглядає сім'ю, як екологічну нішу. Сім'я - це створена людиною інтимна середовище існування. Однією з умов існування є взаємини в сім'ї. Як народжуються i виховуються діти, як ведеться господарство, як задовольняються інтереси всіх іiі членів. Взаємовідносини, повага, підтримка, розуміння визначають взаємини. Яке здоров'я родичів, їх характер і вчинки.

Взаємовідносини у сім'ї залежить від традицій, спілкування, економічного i соціального стану суспільства, залежно сім'ї від суспільства, участі подружжя у веденні господарства, у суспільному виробництві, від типу родини: багатодітна, бездітна, хто головує, від особистих якостей характеру родичів [5].

У зв'язку з цим ми вважаємо за необхідне розширити поняття сім'ї, так як сім'я - це не просто мала соціально - психологічна група, яка пов'язана шлюбними i родинними відносинами, а й створення нового життя, це будинок в якому виховується і розвивається особистість, закладаються моральні основи, формується світогляд. Сім'я сприяє не тільки формуванню особистості, а й самоврядуванню людини, стимулює його соціальну творчу активність, розкриває індивідуальність. Адже життя в рідній сім'ї - це найбільш потужне переживання, що визначає всю подальшу нашу життя. Його вплив не обмежується одними діями. Якими ми бачимо себе, інших і весь світ - все це визначається установками нашої рідної сім'ї. Погляди розвинулися в ній, залишаються 3 нами протягом усього життя [6]. 
Мета статті - аналіз наукових праць щодо ролі сімейного педагога у структурі територіального центру соціальної допомоги сім’ї та дітям та формування у старшоклассників відношень до сім'ї як соціально значущих цінностей в умовах проектної діяльності.

Виклад основного матеріалу. Сімейний соціальний педагог у процесі своєї діяльності вирішує багато проблем сім'ї. Але, щоб його діяльність була ефективною, потрібна батьківська підтримка, щоб батьки усвідомлювали, що їм хочуть допомогти, що все те, що робить соціальний педагог - для їхнього блага. Недарма ж А.С. Макаренко був глибоко впевнений, що «батьківські вимоги до себе, батьківське повагу до своєї родини, батьківський контроль над кожним своїм кроком - ось перший і найголовніший метод виховання, а якщо 3 дитиною неблагополучно, потрібно, перш за все, самого себе покласти під мікроскоп. I треба не дитини перевиховувати, а змінювати своє ставлення до нього, тому що його ставлення до себе залежить тільки від батьків» [7].

Від поведінки батька і матері, їх ролі у вихованні дітей залежить статус сім'ї. Чи будуть зразком для дітей батьки, адже відсутність їх негативно впливає на розвиток дитини.

Допомога соціального педагога батькам в основному полягає в консультуванні, організації психологічних тренінгів, навчання поводження 3 дитиною, організації спільного з дитиною відвідин клубів сімейного відпочинку, здійсненні психолого-педагогічної роботи 3 дітьми та молоддю за місцем проживання, виявлення особистих, міжособових i сімейних труднощів i конфліктів , фактів відхиляється від норми поведінки, сімей соціального ризику. Виявлення дітей, підлітків, які потребують опіки та піклування, вчиненні їм необхідної допомоги. Також соціальний педагог займається профілактикою правопорушень, дитячого, побутового, дорожньо-транспортного травматизму, пожеж. Забезпечує дотримання техніки безпеки та санітарно - гігієнічних норм при проведенні роботи 3 населенням, вживання заходів 3 надання (при необхідності першої медичної допомоги).

Як будь-яка діяльність, діяльність соціального педагога за рішенням сімейних проблем повинна бути цілеспрямованою, спланованою, грамотно організованою. У зв'язку з цим ми вважаємо за необхідне розгляд наступних питань: принципи та напрямки, схема системного аналізу, алгоритми роботи 3 важкими сім'ями.

При роботі з сім'єю соціальний педагог спирається на наступні принципи:

1) принцип гуманізму (визнання людини, як самоцінної особистості, його право на свободу, щастя, прояв своїх здібностей);

2) особистісно - діяльнісний підхід (ставлення до дитини як суб'єктної діяльності, в ході якої йде соціалізація особистості, ставлення до сім'ї як до самоцінності. Захист почуття довіри і збереження сім'i);

3) культурно-логічний принцип (робота в контексті культури життєдіяльності духовних цінностей, захоплень і т.д.);

4) принцип життєдіяльності та виховання (передбачає цілісність зусиль різних організацій та осіб, що займаються вихованням i захистом в організації 
прав дітей);

5) принцип розвивального спілкування (прийняття людини таким, яким він $\epsilon$, спілкування на правах партнерства);

6) принцип поєднання терпимості поваги та вимогливості до особистості дитини і до себе;

7) принцип урахування нових тенденцій розвитку і функціонування соціуму, забезпечення допустимого і доцільного посередництва в системі взаємодії особистості, сім'ї, суспільства;

8) принцип милосердя.

Також соціальний педагог спирається на п'ять напрямків у своїй діяльності.

- Робота з сім'єю, як з інститутом соціо - культурного відтворення людини, вона включає в себе психолого-педагогічну діагностику, проблеми труднощів конкретно сім'ї 3 несприятливим психологічним мікрокліматом, багатодітній, неповної, студентської, сім'ї з особами провідними кримінальний спосіб життя. Соціальна педагогічна допомога сім'ї - дуже інтенсивне, адресне обслуговування та консультування сім'ї. Важливо самоосвіта батьків, що включає в себе самостійне читання спеціальної за рекомендацією соціального педагога літератури.

- Надання допомоги важкого дитині, підлітку у вирішенні проблем адаптації в суспільстві. У такій допомоги потребують діти, які опинилися в несприятливих умовах, що загрожують їхньому здоров'ю та розвитку: жертви жорстокого поводження в сім'ї, діти які знаходяться в тривалому конфлікті з батьками, друзями, однолітками і т.д. Таким дітям властиві нестійкість уваги, дратівливість, слабкість неправильного виховання в сім'ї;

- Профілактична робота - це профілактика трудновоспитуемости;

- Організація творчої діяльності дітей відбувається на базі центрів для дозвілля: ДДТ, природно-охоронна діяльність, спортивно - оздоровчі комплекси і т.д. Сімейний соціальний педагог входить в контакт 3 фахівцями, співпрацюючи 3 ними.

- Соціальна адаптація дітей - набуття ними позитивного взаємодії 3 оточуючими, активне самоствердження в середовищі [8].

Одним з основних підходів у вирішенні сімейних проблем у діяльності соціального педагога може бути системний підхід. У рамках системного підходу впливів соціального педагога 3 сім'єю представляється у вигляді сукупності взаємопов'язаних, взаємозалежних і організованих елементів, тобто системи.

В основному соціальному педагогу в своїй практиці доводиться стикатися 3 тими сім'ями, які мають значні проблеми у виконанні різних функцій. До них належать сім'ї «групи ризику», асоціальні, неблагополучні. Часто такі родини називають одним словом - важкі за аналогією 3 «важкими» дітьми. Дійсно, взаємодія з ними і процес вирішення внутрішньосімейних проблем у таких сім'ях значно ускладнений.

Сім'я виступає як спеціальний об'єкт соціального впливу, коли педагогічні зусилля спрямовуються на нейтралізацію іï негативних впливів на дітей, розбудову відносин у сім'ї, створення основного формування соціально-значущих 
цінностей. Не можна чекати від сім'ї того, що вона сама почне займатися подоланням труднощів, тому що багато проблем можуть здаватися не небезпечними.

Успіх цього визначається також умінням сімейного соціального педагога підбирати актив в будинку, де проживає сім'я, створювати опору з числа найбільш зацікавлених жителів, сусідів і т.д. Поле діяльності соціального педагога при цьому - активне вивчення соціально-педагогічних можливостей мікрорайону, позитивний вплив на несприятливі сім'ї, підтримка школи. Вище вже йшлося про те, що в залежності від типу, кожна сім'я має свої специфічні проблеми. У цій частині нашої роботи ми розглянемо особливості діяльності сімейного соціального педагога з різними типами сімей.

Розглянувши конкретну роботу з родиною ми вважаємо за потрібне зробити акцент на системах соціально - педагогічної підтримки сімей. Під підтримкою ми розуміємо перспективну i оперативну допомогу дітям, сім'ї у вирішенні їх проблем.

Виявляючи проблеми і труднощі в сфері сім'ї учня, у сфері внутрішкільного спілкування і взаємини, соціальний педагог у процесі діагностики диференціює виявлені проблеми і «виводить» на їх вирішення інших фахівців - професіоналів: психологів, лікарів, юристів, соціальних працівників, представників органів влади, громадськості.

Практичне побудова системи соціально - педагогічної підтримки дитинства в кожному конкретному муніципальному освіті має здійснюватися з урахуванням місцевої специфіки не тільки соціальних проблем дітей та молоді, але й економічних, організаційних та інших можливостей даного суб'єкта місцевого самоврядування.

Структурно - функціональна модель. Перший рівень передбачає організацію нововведень соціально - педагогічного змісту в типових загальноосвітніх установах. Складові системи даного рівня покликані надавати ефективну допомогу кожній дитині в подоланні навчально-виховних проблем. Перша складова пов'язана 3 необхідністю раннього виявлення дітей групи ризику та надання їм соціально - педагогічної підтримки. Вона включає спеціально організовані соціально - педагогічні групи в дошкільних освітніх установах, діяльність яких допоможе вирішити проблеми фізичного i психологічного здоров'я дітей з неблагополучних сімей, їх повноцінного виховання і підготовки до школи. Раніше, коли дошкільні установи були доступні сім'ям з будь-яким матеріальним достатком, їх відвідували майже всі діти, в тому числі і діти 3 неблагополучних сімей. В даний час для багатьох, навіть працюючих батьків виховання дітей у дошкільних установах стало неможливим в силу значно збільшується вартості їх змісту. У великій мірі це торкнулося сім'ї безробітних, біженців та переселенців, неповні та багатодітні родини, соціальні сім'ї. Для дітей 3 цих сімей необхідно створити спеціальні групи у дитячих садках, які повинні працювати цілодобово в цілорічному режимі i перебувати на повному державному забезпеченні. Створення таких груп - важлива ланка в системі соціально - педагогічної підтримки. Виявлення цих дітей та надання їм допомоги 
на ранніх стадіях дозволяє більш успішно соціалізуватися, запобігати або істотно зменшувати можливість виникнення соціальних відхилень у розвитку і поведінці.

До групи соціальних служб належать також спеціалізовані групи для дітей мають проблеми в розвитку (порушення мови, слуху, зору, опорно-рухового апарату, ослаблене здоров'я, та інші), а також спеціалізовані дитячі садки для них.

Друга складова цього рівня включає спеціалізовані класи в загальноосвітніх установах, які об'єднують дітей з певними проблемами. Існує кілька можливих різновидів навчальних класів, що відповідають різним станам ризику дітей 3 неуспішністю або дезадаптацією: класи компенсуючого навчання (або педагогічної підтримки) для учнів ризику академічної неуспішності; класи корекційно-розвивального навчання для учнів ризику по здоров'ю; профільні класи соціального ризику.

Третя складова об'єднує різні установи додаткової освіти, дозвілля та відпочинку дітей (дитячі спортивні школи, літні оздоровчі табори), діяльність яких має соціально - педагогічну спрямованість. Це і соціально - педагогічні групи в різних секціях, гуртках, студіях, а також спеціалізовані зміни і загони у таборах літнього відпочинку.

У цілому діяльність установ і служб першого рівня спрямована на корекцію соціально - педагогічних умов реалізації прав дітей на повноцінний розвиток $\mathrm{i}$ освіта в рамках традиційних освітніх установи.

Таким чином, учні першого рівня виконують, перш за все, освітньокорекційну функцію.

Другий рівень муніципальної системи соціально - педагогічної підтримки дитинства передбачає створення закладу нового типу - соціально - педагогічних закладів. Потреба в них викликана появою численних категорій дітей групи ризику, проблеми їх не вирішують типові освітні установи: діти, що залишилися без піклування батьків, діти не мають житла і прописки; діти - біженці, діти 3 неблагополучних сімей; відчувають розно виду ситуації в сім'ї або суспільстві . Інноваційні соціально - педагогічні установи покликані захищати невід'ємне право дитини та надавати йому необхідну допомогу та підтримку; надавати дітям можливість тимчасового проживання, забезпечувати їх їжею і одягом, медичною допомогою, створювати умови для соціальної адаптації та реабілітації.

Виділені типи необхідні в будь-регіональній системі соціально педагогічної підтримки дитинства.

Центр соціально - трудової адаптації (ЦСТА) призначений для неповнолітніх підлітків групи ризику, відрахованим 3 різних причин із загальноосвітніх установ. Головне завдання ЦСТА - створення умов для соціальної адаптації, що включають професійну орієнтацію, професійне навчання, працевлаштування, правовий захист i контроль за дотриманням їх прав у сфері виробництва. Тому в структуру ЦСТА обов'язково повинні входити: центр профорієнтації, молодіжна біржа праці, освітній центр початкового професійного навчання підлітків.

Центр сімейного виховання (ЦСВ) вирішує проблеми дітей, які виховуються 
в неблагополучних сім'ях. Основне завдання центру - усунення або пом'якшення соціальних, економічних, психологічних впливів неблагополучної сім'ї, що надає негативний вплив на розвиток дитини і в той же час їі збереження і реабілітація, 3 тим щоб не відбулася ізоляція дитини від батьків. Для вирішення цього завдання центр працює в наступних напрямках соціально - педагогічної допомоги:

1) виявлення неблагополучних сімей та їх соціальна реабілітація, мета якої зберегти сім'ю, змінити в позитивний бік ставлення батьків до дітей, поліпшити соціально - економічну та психологічну ситуацію в сім'ї, підвищити правові, педагогічні, психологічні знання батьків;

2) організація денного перебування дітей з неблагополучних сімей. Центр представляє необхідні умови для їх повсякденної життєдіяльності і розвиток яких не забезпечує сім'я;

3) організація в мікрорайонах дозвілля та відпочинку дітей цієї категорії, створення можливості безкоштовно знайти заняття за інтересами, реалізувати свої творчі здібності та нахили. Ці напрямки діяльності здійснюються через такі структурні підрозділи ЦСВ: службу сім'ї, Центри денного перебування дітей, дозвільні центри за місцем проживання.

Центр невідкладної соціально - психологічної допомоги (ЦНП) повинен оперативно вирішувати проблеми дітей, які опинилися в психологічній складній ситуації, пережили насильство, стрес, тимчасово залишилися без житла та засобів до існування, які пішли 3 дому, бродяжать, безпритульних і бездоглядних. Головні завдання центру - забезпечення охорони та захисту прав (визначення соціального статусу дитини, з'ясування правових аспектів його життєвої ситуації та необхідних правових дій), напрямок дитини до органів правомочні вирішувати його ситуацію, надання практичної соціальної допомоги, охорона від впливу асоціальної середовища, надання психологічної допомоги , консультування 3 питань правового, соціального, психологічного, педагогічного характеру.

У центрі діти залишаються до вирішення їх проблем або визначення їх соціально - правового статусу і подальшої долі.

Кризовий центр (КЦ) призначений для дітей - сиріт та дітей залишилися без піклування батьків. Головне завдання центру - соціально - педагогічна реабілітація цих дітей та сприяння їх соціальній адаптації КЦ включає у свою структуру: притулок тимчасового перебування, в якому діти можуть перебувати до 6 місяців, поки вирішуються різні правові питання їх життєвої ситуації.

Муніципальний дитячий будинок, в якому діти залишаються до повноліття і початку самостійного життя.

Діяльність цих соціально - педагогічних закладів націлена на реалізацію та захист порушеного права дітей на рівень життя, необхідного для їх повного розвитку, на їх соціально - педагогічну реабілітацію.

Таким чином, їх основна функція - правозахист, соціальна адаптація та соціальна реабілітація.

Третій рівень - управлінський, який включає власне муніципальний орган управління освітою, а також що знаходиться в його безпосередньому підпорядкуванні психолого-медико-педагогічну службу, що забезпечує 
виявлення i діагностику соціально - педагогічних проблем дітей в рамках муніципального освіти.

Психолого-медико-педагогічна комісія, що працює на постійній основі здійснює комплектацію спеціалізованих груп і класів освітніх установ з числа дітей як відвідують освітні установи, так i перебувають у соціально педагогічних закладах.

Запропонована регіональна модель захисту дитинства і сім'ї.

1) Профілактична допомогу. Мова йде про позавідомчих регіональних та територіальних центрах соціально - психологічної допомоги дитині та сім'ї, що створює у своїй структурі ряд спеціалізованих установ або консолідуючих діяльність вже існуючих.

Необхідно включення психолого-медико-педагогічної комісії (консультації) в структуру цих центрів, що дозволить уникнути притаманну чинним організаціям відомчу обмеженість.

Друга необхідна ланка - це Раду з проблем дитинства та сім'і. Ця структура, що володіє основними розпорядчими функціями і керуюча фінансуванням, крім відомчих законів повинна створити умови для реалізації єдиної політики в суб'єктах

2) Контроль за дотриманням прав дітей. Деякі принципові моменти служби уповноваженого з прав дитини. Діяльність уповноваженого доповнює існуючі засоби захисту прав; свобод і законних інтересів дитини, хоча не відміняє і не тягне за собою перегляду компетенції органів державної влади, громадських об'єднань і комерційних організацій суб'єкта, оскільки ця служба не володіє ніякими розпорядчими або які санкціонують повноваженнями, а тільки правове спостереження та інформування.

3) Захист прав дітей. Безпосередня функція - захист прав дітей 3 організовано - розпорядчими повноваженнями покладається на комісію у справах неповнолітніх і захисту їх прав. Основна мета - захист прав та інтересів дітей, а також координація заходів з профілактики, бездоглядності та правопорушень дітей відповідних відомств та організацій.

На жаль, набагато більш сумна історія відбувається з ювенальної юстицією цим необхідною ланкою реабілітаційного простору, основним завданням якого є профілактика соціальної дезадаптації дітей і підлітків. Проте, до цих пір не зроблено жодних реальних кроків у цьому напрямку. Між тим, очевидно, що включення у регіональну систему захисту дитинства сім'ї місцевих ювенальних судів давно назріло у нашій країні.

3. Система педагогічної підтримки в загальноосвітньому закладі включає в себе: наявність у школах лікарів - педіатрів і медсестер, у завдання яких входить диспансеризація всіх дітей та здійснення щеплень; районні лікарі психоневрологи, дефектологи, логопеди ведуть діагностичну роботу і надають допомогу дітям, яких направляють школи; класні керівники - ведення документації, контроль за відвідуваністю і дисципліною спілкування з батьками, проведення класних зборів, бесід на моральні теми, організація тематичних навчальних зустрічей, екскурсій, походів, вечорів відпочинку, організація участі 
класу в загальношкільних святах, творчих конкурсах, спортивних змаганнях; заступник директора з виховної роботи, який крім завдань соціалізації вирішує питання роботи з батьками, 3 важкими дітьми, здійснює координацію із зовнішніми службами; психологічна служба - шкільний психолог, соціальний педагог.

Соціально - педагогічна допомога сім'ї - це дуже інтенсивне адресне обслуговування та консультація сім'ї. Вона використовується там, де інші форми не дають ефективних результатів. Виникла необхідність створення служби, яка об'єднала б висококваліфікованих фахівців у галузі педагогіки, психології, медицини і права 3 метою надання практичної допомоги сім'ям, важким сім'єю, важким дітям, соціальним педагогам і співпрацю $з$ ними.

Вирішення проблем особистісного розвитку дитини питань сім'ї в цьому центрі дозволяє соціальному нужденним, бути в більш тісному контакті 3 родиною і вдосконалюватися.

Завдання:

1) діагностувати соціально - психологічні та педагогічні ситуації в сім'ї, мікросоціумі;

2) вивчати інтереси і потреби дітей i дорослих, їхні труднощі, проблеми сімей з різним сімейним життєвим укладом;

3) допомога адаптації сім'ї до змінних соціально - економічних умов, зберігаючи все позитивне що було їй властиво в загальнолюдському плані;

4) вести профілактичну роботу 3 сім'єю, дитиною, надавати психологопедагогічну підтримку людям 3 лабільною нервовою системою;

5) сприяти оздоровленню середовища в контакті з соціальним педагогом;

6) підвищувати психолого-педагогічну культуру сімей;

7) захищати інтереси дитини спільно з сімейним соціальним педагогом;

8) встановлювати в міру необхідності контакти 3 іншими соціальними інститутами виховання, через посередництво сімейного соціально педагога для надання більш ефективної допомоги аж до ізоляції дитини 3 неблагополучної середовища;

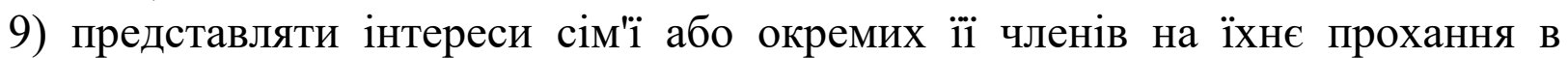
державних і громадських організаціях через посередника - сімейного соціального педагога [9].

Таким чином підвищується психолого-педагогічна культура батьків, у сім'ї з'являється підтримка - сімейний соціальний педагог і конкретна компетентна служба, зацікавлена в створенні комфортної, безпечного середовища для нормального і успішного розвитку дітей та їх захисту.

Отже, ми розглянули діяльність соціального педагога в сім'ї і в процесі роботи прийшли до наступних висновків.

Висновки. Сім'я в своєму становленні у розвитку соціо - культурних традицій проходить ряд етапів. При цьому необхідно відзначити високу значимість сім'ї на всіх етапах: як соціального інституту, екологічної ніші, інституту соціалізації, інтимної середовища існування. Сучасний стан сім'ї носить кризовий характер, тому одна з цілей діяльності соціального педагога $є$ 
відновлення соціальної психологічної культурно - моральної цінності сім'ї. Сучасні автори дають різні поняття сім'ї в основному вони засновані на визнанні нормативно - моральних відносин членів сім'ї. Ми ж хотіли зробити акцент на социализирующей функції сім'ї в окремо взятої особистості. На нашу думку сім'я - це не просто мала соціально - психологічна група, яка пов'язана шлюбними i родинними відносинами, а й створення нового життя, - це будинок в якому виховується і розвивається особистість, закладаються моральні основи, формується світогляд.

Кожна сім'я виконує ряд функцій. Ми вважаємо можливим звести їх до чотирьох основних: виховної, репродуктивної, господарсько - побутової, дозвільної. Основний з яких ми вважаємо виховну функцію.

У залежності від складу, етапу свого становлення, рівня благополуччя виділяють різні типи сімей.

Нас насамперед цікавить класифікація різних типів сімей за ступенем їх благополуччя. Це дає можливість визначити необхідність, пріоритет і напрями діяльності соціального педагога при вирішенні сімейних проблем. Основними принципами соціального педагога при роботі $є$ : принцип гуманізму, особистісно діяльнісний підхід, культурологічний принцип, принцип життєдіяльності та виховання, принцип розвиває спілкування, принцип поєднання терпимості, поваги і вимогливості до особистості дитини і до сім'ї, принцип обліку нових тенденцій розвитку і функціонування соціуму , принцип милосердя.

Велике значення для підвищення психолого-педагогічної культури батьків та усунення негативних чинників, що впливають на розвиток сімей, мають різні центри. У сім'ї з'являється підтримка - сімейний соціальний педагог і конкретна компетентна служба. Особливу увагу приділяється сім'ям «групи ризику», тому що відхилення у поведінці дітей та підлітків залежить від благополуччя сімейного виховання.

Ми вважаємо, що процес роботи з сім'єю повинен бути цілеспрямованим, послідовним, при цьому важливо усвідомлювати бажаний результат. Тобто, процес роботи з сім'єю повинен бути технологічний. Пошук технології роботи 3 різними типами ми розглянули в практичній діяльності. В основі використовували метод соціального діагностування. Метою роботи було визначення причини девіантної поведінки дитини на основі аналізу сімейного виховання.

Таким чином, діяльність сімейного соціального педагога необхідна по роботі 3 сім'єю, тому що сучасне суспільство потребує фахівців, які змогли б вирішити соціальні проблеми, тим самим позитивно вплинути на розвиток і виховання дитини в сім'ї, усуваючи негативні фактори соціалізації, впливають на підліткову особистість.

\section{Лimepamypa:}

1. Василькова Ю.В. Методика и опыт работы социального педагога : [уч. - метод. пособие] / Ю. Василькова. - М. : Академия, 2009. - 198 с. 
2. Лукашевич М.П. Соціалізація. Виховні механізми і технології : [навч. - метод. посібник] - К. : ІЗМН, 2008. - 112 с.

3. Методика и технологии работы социального педагога : [уч. пос. для студ. высш. уч. зав.] / Б.Н. Алмазов, М.А. Беляева, Н.Н. Бессонова и др. - М. : «Академия», 2012. - 192 с.

4. Методика и технологии работы социального педагога : [уч. пос. для студ. высш. уч. зав.] / П.р. Галагузовой Ю.Н. - М. : ВЛАДОС, 2010. - 324 с.

5. Овчарова Р.В. Справочная книга социального педагога / Р. Овчарова. - М. : ТЦ «Сфера», 2001. - $480 \mathrm{c}$.

6. Соціальна педагогіка : [підручник] / За ред. проф. Капської А.Й. - К.: Центр учбової літератури, 2011. - 488 с.

7. Соціальна педагогіка : [модульна технологія навчального курсу] / Д.І. Пенішкевич, Л.I. Тимчук. - Чернівці : Чернівецький нац. у-т, 2010. - 496 с.

8. Соціальна педагогіка : [мала енциклопедія] / За заг. ред. проф. І.Д. Звєрєвої. - К.: Центр учбової літератури, 2008. - 336 с.

9. Шептенко П.А., Вороніжа Г.А. Методика и технологии работы социального педагога : [уч. пос. для студ. высш. пед. уч. зав.] / П.р. В.А. Сластенина. - М. : «Академия», 2001. - 208 с.

\section{References:}

1. 1. Vasil'kova Ju.V. (2009). Metodika i opyt raboty social'nogo pedagoga [Methodology and work experience of a social teacher]. Moscow: Akademija [in Russian].

2. Lukashevich M.P. (2008). Socializacija. Vihovni mehanizmi i tehnologii [Socialization. Educational mechanisms and technologies]. Kyiv: IZMN [in Ukrainian].

3. Almazov B.N., Beljaeva M.A., Bessonova N.N. et al. (2012). Metodika i tehnologii raboty social'nogo pedagoga [Methods and technologies of work of a social teacher]. Moscow: «Akademija» [in Russian].

4. Galaguzovoj Ju.N. (2010). Metodika i tehnologii raboty social'nogo pedagoga [Methods and technologies of work of a social teacher]. Moscow: VLADOS [in Russian].

5. Ovcharova R.V. (2001). Spravochnaja kniga social'nogo pedagoga [Social Educator Reference Book]. Moscow: TC «Sfera» [in Russian].

6. Kaps'ka A.J. (2011). Social'na pedagogika [Social pedagogy]. Kyiv: Centr uchbovoj literaturi [in Ukrainian].

7. Penishkevich D.I. \& Timchuk L.I. (2010). Social'na pedagogika [Social pedagogy]. Chernivci: Chernivec'kij nac. u-t [in Ukrainian].

8. Zvereva I.D. (2008). Social'na pedagogika [Social pedagogy]. Kyiv: Centr uchbovoj literaturi [in Ukrainian].

9. Slastenina V.A., Sheptenko P.A. \& Voronizha G.A. (2001). Metodika i tehnologii raboty social'nogo pedagoga [Methods and technologies of social pedagogue]. Moscow: «Akademija» [in Russian]. 